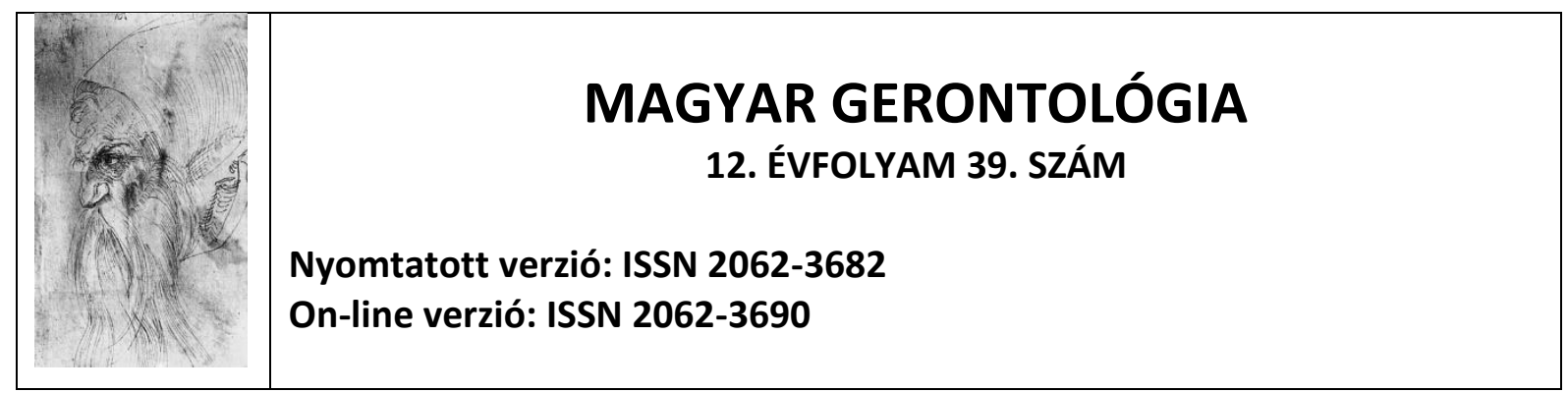

\title{
AZ IDŐSEBB KOROSZTÁLY SZEREPE A CSALÁDI GAZDASÁGOK GENERÁCIÓVÁLTÁSÁBAN
}

\author{
Kovács Éva Katalin \\ Debreceni Egyetem, Gazdaságtudományi Kar, Vidékfejlesztés, Regionális Gazdaságtan és \\ Turizmusmenedzsment Intézet
}

Levelezési cím: Kovács Éva Katalin, kovacs.eva.katalin@econ.unideb.hu

Telefonszám: +36306929793

A családi gazdaságok életében éppúgy, mint a gazdaság más területein az egyik legnagyobb kockázatot a generációváltás, azaz a gazdaság átadása jelenti. Ezt bizonyítja a tény is, miszerint a vállalatok 2/3-a nem éli túl a generációváltást. Ennek ellenére mégis sok gazdaság kockáztatja fennmaradását azáltal, hogy nem tervezik meg az utódlást. Az utódlás folyamatában a központi szerepet az elődök töltik be. Jelen tanulmány célja az idősebb korosztály szerepének vizsgálata a családi vállalkozások generációváltásában, - korábbi empirikus kutatások alapján. Az elödök az utódlást követően is szimbolikus szereppel bírnak, így nagy hatással vannak a céges kultúrára, értékekre és teljesítményre. Az elődök széleskörü tapasztalattal rendelkeznek a gazdálkodást tekintve, azonban járatlanok az utódlás területén. Többük fejében megszületik a nyugdíjba vonulás gondolata, azonban a tényleges cselekvésig csak kevesen jutnak el. Végezetül pedig elmondható, hogy a családi gazdaságok legföbb előnye az lehet, hogy ideális esetben akár generációkon át egy család kezében maradnak, ezáltal több tíz évnyi tapasztalat és tudás, információ és rutin összpontosulhat a vezetöben, a kapcsolati tőkéről nem is beszélve. Így nem szabad elfelejtenünk, hogy az ezüstgeneráció aranyat ér!

Kulcsszavak: utódlás, generációváltás, családi gazdaság, idős korosztály 


\section{THE ROLE OF ELDERLY GENERATION IN GENERATIONAL TURNOVER OF FAMILY FARMS}

One of the greatest risks of a family farm is the succession of the farm. It is also backed by the fact that $2 / 3$ of the companies do not survive the generational turnover. However, several farm risk their survival by not planning succession. Predecessors play a major role in the succession process. Thus, the aim of the study is to examine the role of the elderly generation in generational turnover of family businesses based on earlier empirical research. The predecessors continue to play a symbolic role after succession and thus have a profound impact on corporate culture, values and performance. The predecessors have extensive farming experience but are inexperienced in succession. Several of them contemplate on retirement, but few actually get to action. In conclusion, the core benefit of family farms is that, ideally, they remain in the control of a family for generations, thus allowing tens of years of experience and knowledge to be concentrated in the leader. Therefore, we should not forget that the silver generation is worth gold!

Key words: succession, generational turnover, family farm, elderly generation

\section{Bevezetés}

A legtöbb magyar vállalkozást a rendszerváltást követően, az 1990-es évek elején hozták létre. Ebből kifolyólag napjainkra az akkori vállalatalapítók már nyugdíj körüli korban vannak. Így égető kérdéssé vált számukra, hogy a cégüket képesek-e a következő generációra átörökíteni.

A magyar vállalkozások többsége első generációs, ezért nem áll rendelkezésre elözetes tapasztalat a generációváltásról. A sikeres generációváltás ugyanakkor társadalmilag is fontos ügy a családi tulajdonban levő vállalkozások gazdasági súlyának köszönhetően. A családi vállalkozások ugyanis jelentős szerepet töltenek be (foglalkoztatás, GDP) a piacgazdaságokban (Csákné 2012: 11). A Noszkay (2017) által hivatkozott adatok szerint az EU-ban a vállalkozások között a családi cégek aránya 70-80\%, mely a foglalkoztatásból 40-50\%-os, míg a GDP-ből 20-70\%-os részesedést jelent. A magyar vállalatok 70\%-a van családi tulajdonban, melyek mind a GDP, mind pedig a foglalkoztatás 50\%-át biztosítják.

A 2010-es Általános Mezőgazdasági Összeírás (továbbiakban: ÁMÖ) adatai alapján az idősebbek aránya jóval magasabb a fiatalokénál, vagyis a belépő fiatalok száma nem tudja pótolni a kilépő idősebbekét a magyar mezőgazdaságban. A megfelelő számú utánpótlás hiánya veszélyeztetheti a gazdaságok fennmaradását. Összevetve a korábbi adatokkal megfigyelhető, 
hogy tíz év alatt ugyan minden korosztályban csökkenés történt a mezőgazdasági tevékenység végzésében, azonban sokkal több fiatal hagyott fel a vele, mint idős.

A családi gazdaságok életében az egyik legnagyobb kockázatot a generációváltás kérdése jelenti. Az utódlással kapcsolatos aggodalmak egyáltalán nem indokolatlanok, hiszen a vállalatok 2/3-a nem éli túl a generációváltást. A családi cégek alapjában véve ambiciózus, növekedni akaró, hosszútávra tervező vállalkozások. Ennek ellenére mégis sokan kockáztatják a vállalat fennmaradását azzal, hogy nem tervezik meg az utódlást.

A tanulmány célja a családi vállalkozások generációváltásában érintett idősebb korosztály, azaz az elődök szerepének vizsgálata korábbi empirikus kutatásokra alapozva. A tanulmány szekunder kutatásként korábbi szakirodalmi forrásokat dolgoz fel és hasonlít össze.

\subsection{A családi gazdálkodás fogalmi lehatárolása}

A családi gazdaság meghatározására számos definíció ismert. Ahhoz, hogy pontosítani tudjuk a valódi jelentését elengedhetetlen tisztáznunk a vállalkozó és a gazdaság fogalmát is.

A Magyar értelmező Kéziszótár (2001) és Magda et al. (2003) szerint a „gazdaság” egy olyan mezőgazdasági termelési egység, amely az önálló mezőgazdasági üzemet takarja hagyományosan.

Schumpeter (1980) és Solomon (1991) szerint a vállalkozó olyan innovatív személy, aki a pozitív eredmény reményében saját idejét felhasználva vállalja a felmerülő kockázatokat. Egy más megfogalmazásban a gazdálkodás egy tudatos, tervszerü és összetett tevékenység, mely a mezőgazdasági eredetű javak, szolgáltatások és jövedelmek elöállítását foglalja magában (Dobos, 2000).

Williams (1973) megállapítása alapján a családi gazdaságot a gazda és családja tartja fent bármilyen külső munkaerő felhasználása nélkül. Azonban ez a megfogalmazás hiányosnak mondható, mivel (ahogyan azt a gyakorlat is alátámasztja) bizonyos esetekben a külső munkaerő felhasználás elengedhetetlen. Ebből kifolyólag Juhász (2001) meghatározása pontosabbnak tekinthető, miszerint a családi gazdaságok olyan középparaszti gazdaságoknak tekinthetők, melyek túlnyomó többségben családi munkaerőt használnak fel.

Fehér és Bálint (1991) definíciójában az adott országban és adott időszakra érvényes területnagyságon meghatározott volumenen és a családi munkaerő felhasználásán is hangsúly van. 
Hasonlóan határolta le a fogalmat Burgerné (1992) és Takácsné (1995) akik szerint a családi gazdaság alapvetően a család munka erején alapszik, jövedelemorientált és elsősorban árutermeléssel foglalkozik. A gazdaság alkalmazhat állandó és időszakos munkaerőt is, a termelés pedig történhet saját tulajdonban lévő vagy bérelt földterületen. A gazdaság tulajdonában lévő eszközök kapacitásfeleslegét pedig a vállalkozó bérszolgáltatásként is értékesítheti.

Nehézségeket okozhat, hogy sokszor szinonimaként használunk eltérő definíciókat, mint például a family farm business, gazdálkodó család, mezőgazdasági családi vállalkozás, paraszti gazdaság és a kistermelés. Ezen fogalmak azonban nem összekeverendők, mivel az egyik legfőbb különbség az amerikai farmok és az európai családi gazdaságok között a profitszerzés kihasználása. Hiszen a családi gazdaságok elsődlegesen saját felhasználásra termelnek, és a felesleget értékesítik, míg a farmok fő célja a profitmaximalizálás (Alvincz-Varga, 2000).

A definíciók közötti különbségek Európán belül is léteznek, így azt az adott országra jellemzően kell megfogalmazni. Ebből kifolyólag a 2013. évi CXXII. törvény alapján családi gazdaságnak számít minden olyan gazdálkodási forma, amelyen belül „legfeljebb 300 hektár nagyságú termőföld (ideértve a mező-, erdőgazdasági müvelés alatt álló belterületi földet is) tulajdonával, illetőleg haszonbérletével, használatával rendelkező gazdálkodó család valamennyi termőföldje, az ahhoz tartozó leltárban megjelölt ingatlan és ingó vagyontárgyak (épület, építmény, mezőgazdasági berendezés, felszerelés, gép, állatállomány, készlet stb.) hasznosításával, legalább egy családtag teljes foglalkoztatásán és a többi családtag közreműködésén” alapul. A családi gazdaság tagjai közé sorolható maga a családi gazdálkodó, házastársa vagy élettársa, gyermekei (kiskorú gyermeke, gazdálkodó család tagjaként bejelentett nagykorú gyermeke, illetve örökbe fogadott, a mostoha és a nevelt gyermekei egyaránt) unokái, szülei, nagyszülei és testvérei. A törvény azonban kizárja a családi gazdaság tagjai közül a gazdálkodó házastársának vagy élettársának szüleit, nagykorú gyermekének vagy testvérének házastársát is.

\subsection{A családi gazdaságok sajátosságai}

Vállalkozási formáját tekintve a családi gazdaság speciálisnak mondható, mivel attól függően, hogy mely szervezeti keret bizonyul kedvezőbbnek az adott esetben lehet egyéni vállalkozás vagy akár tulajdonos társulás is (Nábrádi, 2004). Üzleti formáját figyelembe véve pedig a gazdaság és a háztartás nem különíthető el, mivel a család biztosítja a tőke és a munkaerő nagy részét, a megtermelt jövedelem egy része pedig visszaforgatásra kerül a háztartásokba (Gasson-Errington, 1999). 
Egy családi gazdaság ideális összetételét nagyon jól szemlélteti Gasson-Errington (1999) hagyma modellje (1.ábra). A legbelső „magban” a legfontosabb jellemzők találhatók. A vállalkozás tulajdonjoga és az ellenőrzés a vállalkozás vezetőjének a kezében van. A hagyma belsejétől kifelé haladva a kevésbé fontos jellemzők helyezkednek el miszerint a család biztosítja elsősorban a tőkét és a munkaerőt vagy a család benne él a gazdaságban. A rétegességének köszönhetően amennyiben néhány jellemző hiányzik, még mindig megőrzi a formáját. Amennyiben azonban a feltételek közül egyik sem teljesül, nem beszélhetünk családi gazdaságról.

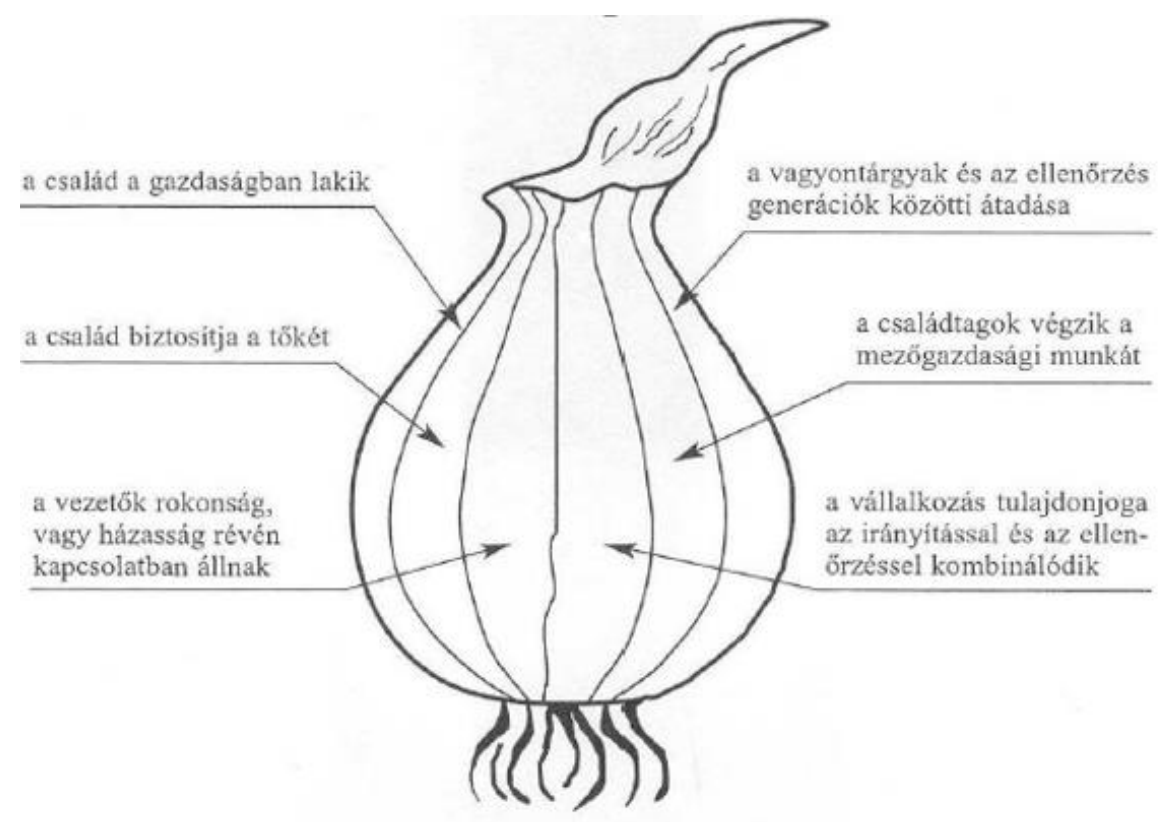

1. ábra: A családi gazdaságot alkotó rétegek (Gasson-Errington, 1999)

A családi gazdaság számos előnye és hátránya is ismert (Nagy, 2006). Legnagyobb előnyei közé tartozik többek között, hogy az adminisztrációs kötelezettséget egy nyilvántartásban kell vezetni. Amennyiben beruházásra kerül sor a beszerzési ár üzembe helyezéskor egyben leírható. A jelenleg hatályos termőföld törvény alapján elővételi és elő haszonbérleti jog illeti meg a családi gazdálkodókat. A bevételeket és a költségeket az adóév utolsó napján meglévő családtagok száma alapján kell felosztani, ehhez pedig az adózás módja választható átalányadózás vagy tételes költségelszámolás formájában. Östermelői tevékenység esetében kötelező a bevételek és költségek megosztása. Számos kedvezményes hitellehetőség és a támogatás áll a gazdák rendelkezésére. A társadalmi tényezőket tekintve pedig a rendelkezésre álló munkaerő sokkal megbízhatóbb, rugalmasabb és motiváltabb, hiszen a saját 
életszínvonaluk növelése a cél, mely érdekében történik a munkavégzés. Nagy előny továbbá, hogy képesek megtermelni saját élelmiszer szükségletüket, ezt követően pedig a felesleget értékesíthetik. Ezáltal szinte minden erőforrás hasznosításra kerül. A család számára pedig a „saját termék tudat” egyfajta biztonságot nyújt. Legnagyobb erény pedig a függetlenség, mivel a gazda itt a „maga ura” lehet és több időt tölthet családjával.

Hátrányok közé sorolható, hogy bizonyos esetekben kisebb termelékenység vagy szakértelem figyelhető meg. Nagyon nehéz a tényleges munkavégzést leellenőrizni, illetve a felelősséget megosztani, mivel családon belül inkább a szóbeli megállapodások a legelterjedtebbek. További gondot okozhat, hogy a munkaerő kínálat a családi ciklus ütemében változik (házasságkötés, halálozás, stb). Amennyiben a gazdaság egy tagja kilép a családi gazdaságból a bevételt és a költségeket fel kell osztani a családtagok között, ami szintén probléma lehet. Ezt követően a csökkent létszám alapulvételével osztható fel az adóév végén a családi gazdaságban maradó tagok között a bevétel és az igazolt költségek (Krenovszkyné, 2014).

\subsection{A ,stafétabot" átadása}

A generációk közti együttmüködés egy szervezetben akkor is kihívásokkal teli, ha még szó sincs az utódlásról (Móré, Bene, 2018). A családi gazdaság egyik alapvető jellemvonása, hogy a tulajdonjog és az irányítás egy kézben van. Ebből kifolyólag ennek átadása a következő generáció számára a vállalkozás jövőjének szempontjából központi kérdés. A generációváltás több okból is létrejöhet. Öröklés esetén a gazdaság vagyontárgyai és a vezetői irányítás is átadásra kerül az utód számára, az idősebb generáció pedig visszavonul.

Gasson - Errington (1999) négy ideális alapesetet fogalmaz meg (3. ábra): 


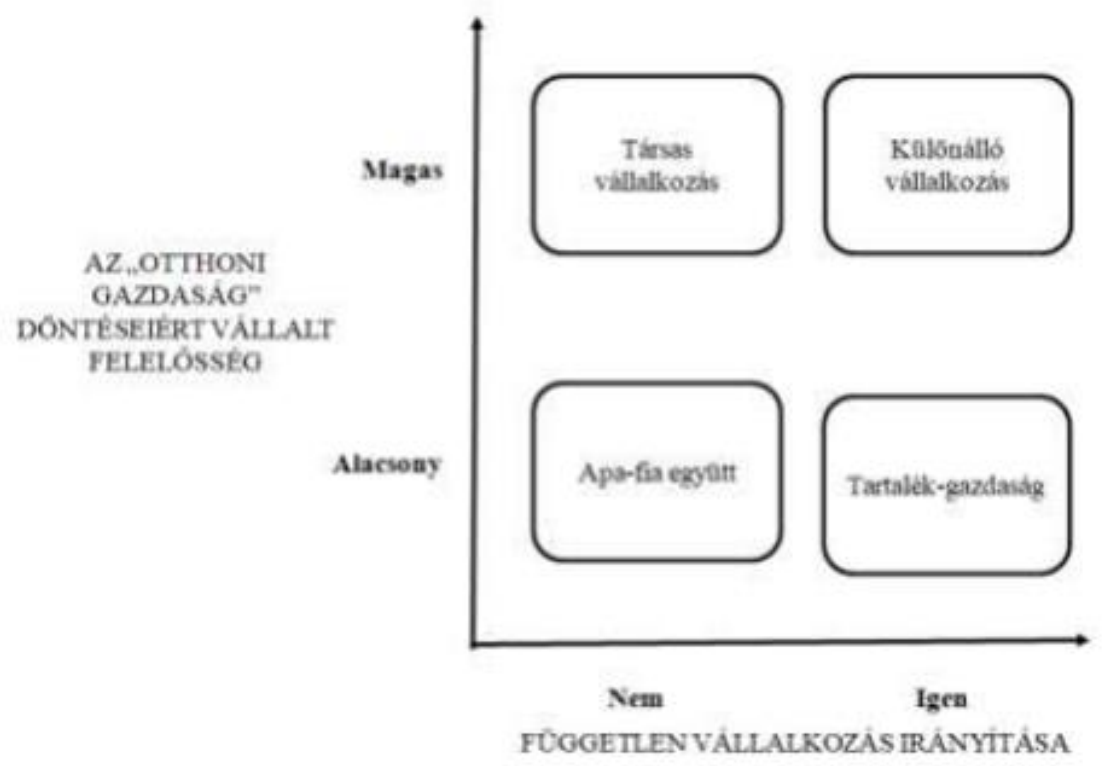

3.ábra: Az utódlás négy esete (Gasson- Errington 1999)

Tartalék gazdaságról akkor beszélhetünk, amikor az utódot az apa egy másik különálló gazdaságba helyezi. Itt az utód tapasztalatot szerezhet, fejlesztheti gazdálkodási és irányítási képességeit. Ebben az esetben az utód pénzügyileg teljesen független, majd az előd nyugdíjbavonulását követően pedig a két gazdaság egyesülhet (Blanc et al., 1992).

Különálló vállalkozás esetén az előd kiszakít egy részt a saját gazdaságából, ahol az utód önállóan tevékenykedhet.

Apa-fia együtt felállás esetében az utód az előddel dolgozik a családi gazdaságban több éven keresztül. Az irányítás az előd kezében van annak nyugdíjbavonulásáig vagy haláláig.

Társas vállakozás esetén pedig az előd csak kisebb döntésekbe vonja be az utódot, majd bizonyos idő elteltével egyre több döntést bíz rá.

Ez a négy ideális eset akár kevert formában is megjelenhet (Gasson - Errington, 1999).

\subsection{Az idősebb korosztály szerepe a generációváltásában}

Poza et al. (1997) szerint a szülök nagyon fontos szerepet töltenek be az utódok gazdaságról alkotott véleményében, azonban nem minden esetben sikerül pozitív véleményt kialakítani. Előfordulhat, hogy az utód nem érdeklődik a gazdaságátadás iránt (Stavrou, 1999). Egyes szerzők szerint, inkább érdemes a gyermekekre hagyni a döntést, hogy mennyire kívánják bevonni magukat a vállalkozás életébe (Birley, 1986, 2002; Birley et al., 1999). A cég 
átvétele vonzó lehet az utódok számára, ha a család tudásbázisa értékes (Royer et al., 2008), mérete jelentős (Huang, 1999) vagy a cég több generációs (Wiklund et al.,2013).

Ma már elengedhetetlen, hogy a gazdaság vezetője birtokában legyen bizonyos mértékig vállalkozói képeségeknek is. Kopasz (2005) szerint a középparaszti és a paraszti nagygazdaságok vezetőiben kialakulhattak különféle vezetői képességek az önálló gazdálkodásnak köszönhetően. Ilyen képességek például a kalkuláció ismerete vagy a piaci jártasság. Napjainkban is megkérdőjelezhetetlen a kapcsolati tőke jelentősége, ennek megteremtése és fenntartása szintén hasznos képesség.

Az utód kiválasztását követően felmerülő legfontosabb kérdés, hogy mi az, amit ténylegesen átad a régi tulajdonos utódjának. A legtöbben ugyanis megtartanák tulajdonosi érdekeltségüket, vagy átadnák azt, ám az irányításban továbbra is részt kívánnak venni. Ezzel szemben az utódok 3/4-e a tulajdonosi és irányítási funkciót egyszerre szeretné megkapni, mely további konfliktusokat eredményezhet (Agronapló, 2017).

Az elődök az utódlást követően is szimbolikus szereppel bírnak, így továbbra is nagy hatással vannak a céges kultúrára, értékekre és teljesítményre. Ebből kifolyólag gátolhatják vagy késleltethetik a döntéshozatalt. Ugyanakkor nagyon nehéz helyzetben vannak, hiszen le kell mondaniuk az általuk felépített hatalomról és befolyásukról utódjuk javára (Le Breton-Miller 2004; Csákné 2012). Az elödök széleskörü tapasztalattal rendelkeznek a gazdálkodást tekintve, azonban gyakran járatlanok az utódlás területén. Még ha többük fejében megszületik is a nyugdíjba vonulás vagy a visszavonulás gondolata, a tényleges cselekvésig csak kevesen jutnak el.

Az idősebbek ragaszkodása a tulajdonhoz és az irányításához erősen fékezheti a fiatalabb generáció kockázatvállalási hajlandóságát és fejlesztési lehetőségeinek kihasználását, amellett, hogy demotiválja őket. Egyértelmű tehát, hogy nagy tétje van az utódlásnak a családi gazdaságon kívül eső területeken is. Ezen okoknál fogva Magyarországon a családi munkaeröre alapozott gazdaságokban csak részben hagyható a nemzedékváltás a természetes folyamatokra. Mindezt felismerve az állam és az unió kiemelten kezelik a fiatalok mezőgazdasági tevékenységének megkezdését, vagy a családi gazdálkodás folytatását. Ehhez különböző ösztönzőket használnak, mint például a KAP 2014-2020 közötti időszakában az I. és II. pillér támogatásai. A források hatékony felhasználásához azonban elengedhetetlen a fiatal generáció szakmai felkészítése, folyamatos információellátása, és tapasztalatszerzési lehetőségeinek biztosítása (Agronapló, 2017). 
A cégen belüli sikeres átmenet lebonyolításában és a harmónia megteremtésében a családtagok közötti cserekapcsolatok alapvető fontosságúak (Bachkaniwala et al., 2001; Malone, 1989). Az utódlás megtervezésének folyamatát azok a családtagok nagyobb mértékben befolyásolhatják, akik közelebbi rokonságban állnak a vállalkozás tulajdonosával. Ezáltal azt is befolyásolják, hogy a gazdaságátadás milyen mértékben alapszik a bizalmon és a lojalitáson (Davis Harveston, 2001; Vallejo, 2008). A családi kapcsolatok igen fontos szerepet játszanak az utódok fejlődésében. Egy összetartó család erősíti a bizalmon és tiszteleten alapuló cserekapcsolatokat (Lansberg - Astrachan, 1994; Seymour, 1993). Mindez Handler (1994) szerint elengedhetetlen a sikeres utódlás lebonyolításához.

A vállalkozáson belüli légkör is befolyásolhatja az utódlás folyamatát (Stavrou et al., 2005). A sikeres gazdaságátadáshoz nem elég önmagában, hogy az utód a gazdaságban dolgozik, elengedhetetlen a közvetlen kapcsolat az előddel (Sardeschmukh - Corbett, 2011).

Végezetül pedig elmondható, hogy a családi gazdaságok legfőbb előnyét az képezi, hogy optimális esetben akár generációkon át egy család kezében maradnak, ezáltal több tíz évnyi tapasztalat és tudás összpontosulhat a vezetőben. Így nem szabad elfelejtenünk, hogy az ezüstgeneráció aranyat ér (Makkos-Káldi et al. 2013)!

„INNOVÁCIÓS ÉS TECHNOLÓGIAI MINISZTÉRIUM ÚNKP-19-3 KÓDSZÁMÚ ÚJ

NEMZETI KIVÁLÓSÁG PROGRAMJÁNAK TÁMOGATÁSÁVAL KÉSZÜLT”
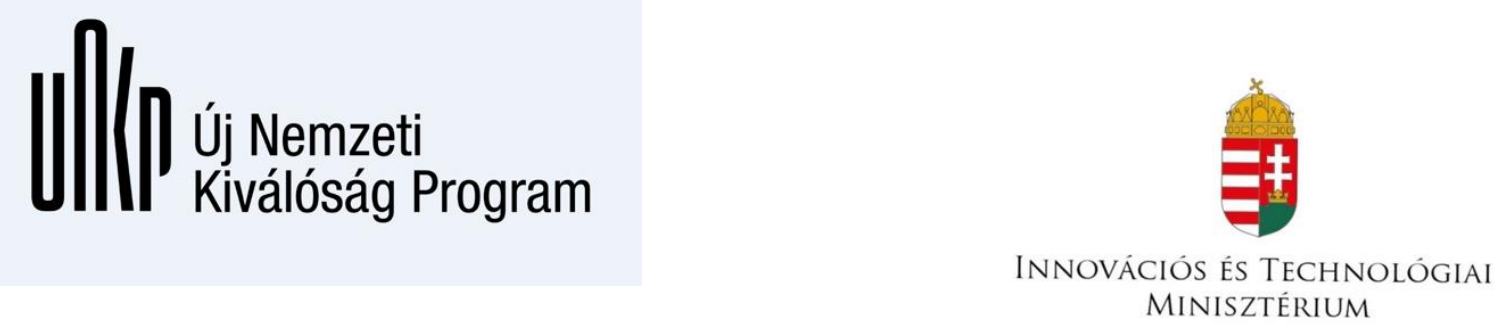

\subsection{Irodalomjegyzék}

Agrya (2017): Gazdaságátadás, nemzedékváltás. Piackutatási jelentés.

Alvincz, J. - Varga, T. (2000): A családi gazdaságok helyzete és versenyképességük javításának lehetőségei, Agrárgazdasági Tanulmányok 15, AKII, Budapest

Bachkaniwala, D. - Wright, M. - Ram, M. (2001): Succession in South- Asian businesses in the UK. International Small Business Journal. 9.15.

Birley, S.- Ng, D. - Godfrey, A. (1999): The family and the business. Long Range Planning, 32, 598-608/.

Birley, S. (1986): Succession in the family firm: The inheritor's view. Journal of Small Business Management, 24(3), 36-43. 
Birley, S. (2002): Attitudes of owner-managers' children towards family and business issues. Entrepreneurship Theory and Practice, 26, 5-20.

Blanc, M. - Perrier, C. - Cornet, P. (1992): Farm Takeover and Farm Entrance Within the European Community. CEE, ENSA Dijon.

Burgerné Gimes, A. (1992): A világ mezőgazdasága. Közgazdasági és Jogi Könyvkiadó, Budapest.

Csákné Filep, J. (2012): Családi vállalkozások - fókuszban az utódlás. Doktori értekezés, BCE, Gazdálkodástani PhD-program. Letölthetö: http://phd.lib.uni-corvinus.hu/660/1/ Csakne_Filep_Judit_dhu.pdf., Letöltés dátuma: 2019.10. 23.

Davis, P. S. - Harveston, P. D. (2001): Th phenomenon of subtantive conflict in the family firm: a cross generational study. Journal of Small Business Management. 39 (1).

Dobos, K. (2000): Családi gazdaságok. Mezőgazdasági Szaktudás Kiadó, Budapest

Fehér, A. - Bálint, D. (1991): A családi gazdálkodás kialakulása Észak-Magyarországon. Gazdálkodás, 1991/7-8.53-63.

Gasson, R. - Errington A. (1999): Családi farmgazdaság adatai. Szaktudás Kiadó Ház Rt.,

Handler, W. C. (1994): Succession in family business: A review of the research. Family Business Review. 7, 133-157.

Huang, T. (1999): Who shall follow? Factors affecting the adoption of succession plans in Taiwan. Long Range Planning. 32 (6).

Juhász, Cs. (2001): Motivation Management in Hungarian Agriculture According to the Hierarchical Levels of Leaders Groups. Buletin of the Symposium „Prospects of the 3trd Millenium Agriculture", Cluj-Napoca

Krenovszkyné, L.A. (2014): Adóügy júliusban: Családi gazdaságok adózása röviden Agro napló,(18. évf.) 7. sz. pp. 9.

Kopasz, M. (2005): Történeti-kulturális és társadalmi tényezők szerepe a vállalkozói potenciál területi különbségeinek alakulásában Magyarországon. (Ph.D. értekezés), Budapesti Corvinus Egyetem, Budapest.

Lansberg, I. - Astrachan, J. (1994): The Influence of Family Relationships on Succession Planning and Training: The Importance of Mediating Factors. Family Business Review. VII (1).

Le Breton-Miller, I. - Miller, D. - Steier, L. P. (2004): Toward an integrative model of effective FOB succession. Entrepreneurship Theory and Practice, 28, 305-328.

Magda, S. (2003): A mezőgazdasági vállalkozások gazdálkodásának alapjai. Mezőgazdasági vállalkozások szervezése és ökonómiája. Szaktudás Kiadó Ház, Budapest.

Magyar Értelmező Kéziszótár (2001): szerk.: Juhász, J. et al, Kilencedik változatlan kiadás, Akadémia Kiadó, Budapest.

Makkos-Káldi, J. - Eisingerné Balassa, B. - Kecskés, P. (2013): Aranyat ér-e az ezüstgeneráció? Tér-GazdaságEmber, 1(1), 119-134.

Malone, S. C. (1989): Selected correlates of business continuity planning in the family business. Family Business Review. 2 (4). 
Móré M, - Bene, Á. (2018): Generational Challenges in Organisations Tudásmenedzsment, 19(1). 15-23.

Nábrádi, A. (2004): A vállalkozás. In.: PFAU E.- NÁBRÁDI A.: A mezőgazdasági vállakozások termelési tényezői, erőforrásai. (Egyetemi jegyzet) Debrecen

Poza, E. J. - Alfred, T. - Maheshwari, A. (1997): Stakeholder perceptions of culture and management practices in family and family firms- a preliminary report. Family Business Review, 10(2).

Royer, S. - Simons, R. - Boyd, B. - Rafferty, A. (2008): Promoting family: A contingecy model of family business succession. Family Business Review,21, 15-30.

Sardeshmukh, S.R. - Corbett, A. C. (2011): The duality of internal and external development of successors: Opportunity recognition in family firms. Family Business Review,24, 111-125.

Schumpeter, J.A. (1980): A gazdasági fejlődés elmélete. Közgazdasági és Jogi Könyvkiadó, Budapest

Seymour, K. C. (1993): Intergenerational Relationships in the Family Firm: The Effect on Leadership Succession. Family Business Review,6.

Solomon, G.T. (1991): Emotional Armor of the American Entrepreneur. The George Washington University

Stavrou, E. T. - Kleanthous, T. - Anastasiou, T. (2005): Leadership Personality and Firm Culture during Hereditary Transitions in Family Firms: Model Development and Empirical Investigation. Journal of Small Business Management, 43.

Stavrou, E. T.(1999): Succession in family businesses: Exploring the effect of demographic factors on offspring intentions to join and take over the business. . Journal of Small Business Management, 37(3), 43-61.

Takácsné, Gy. K. (1995): A családi gazdaságok méretére ható tényezők vizsgálata, különös tekintettel a növénytermesztés gépesítésére. Kandidátusi értekezés, Gödöllő.

Vallejo, M. C. (2008): Is the culture of family firms really different? A value-based model for its survival through generations. Journal of Business Ethics, 81 (2).

Williams, W.M. (1973): The social Study of family farming. In: Mills, D.R. (ed.) English Rural Communities, London

Wiklund, J. - Nordqvist, M. - Hellerstedt, K. - Bird, M. (2013): Internal Versus External Ownership Transition in Family Firms: An Embeddedness Perspective. Entrepreneurship Theory and Practice, 37.

Wulf, T. - Stubner, S. (2008): Unternehmernachfolge in FamilienunternehmenUntersuchungmodell zur Analyse von Problemfelder bei der Übergabe der Fürungrolle. HHL Arbeitspapier Nr. 85. ISSN 1864-4562. 
2013. évi CXXII. törvény

2010-es Általános Mezőgazdasági Összeírás 